Scientia Agricola

http://dx.doi.org/10.1590/0103-9016-2015-0050

\title{
Yield-scaled global warming potential of two irrigation management systems in a highly productive rice system
}

\author{
Silvana Tarlera ${ }^{*}$, María Cristina Capurro ${ }^{2}$, Pilar Irisarri ${ }^{3}$, Ana Fernández Scavino ${ }^{1}$, Guillermina Cantou², Alvaro Roel $^{2}$
}

'University of the Republic/College of Chemistry and Science

- Dept. of Biosciences, General Flores 2124 - Montevideo

- Uruguay.

${ }^{2}$ National Agricultural Research Institute, R. 8 km 281, C.P.

33000 - Treinta y Tres - Uruguay.

3University of the Republic/College of Agriculture - Dept. of Plant Biology, Garzón 809, C.P. 12900 - Montevideo Uruguay.

*Corresponding author <starlera@fq.edu.uy>

Edited by: Axel Garcia y Garcia

Received February 06, 2015

Accepted June 05, 2015
ABSTRACT: Water management impacts both methane $\left(\mathrm{CH}_{4}\right)$ and nitrous oxide $\left(\mathrm{N}_{2} \mathrm{O}\right)$ emissions from rice paddy fields. Although controlled irrigation is one of the most important tools for reducing $\mathrm{CH}_{4}$ emission in rice production systems it can also increase $\mathrm{N}_{2} \mathrm{O}$ emissions and reduce crop yields. Over three years, $\mathrm{CH}_{4}$ and $\mathrm{N}_{2} \mathrm{O}$ emissions were measured in a rice field in Uruguay under two different irrigation management systems, using static closed chambers: conventional water management (continuous flooding after 30 days of emergence, CF30); and an alternative system (controlled deficit irrigation allowing for wetting and drying, AWDI). AWDI showed mean cumulative $\mathrm{CH}_{4}$ emission values of $98.4 \mathrm{~kg} \mathrm{CH}_{4}$ ha-1, 55 \% lower compared to CF30, while no differences in nitrous oxide emissions were observed between treatments $(p>0.05)$. No yield differences between irrigation systems were observed in two of the rice seasons $(p>0.05)$ while AWDI promoted yield reduction in one of the seasons $(p<0.05)$. When rice yield and greenhouse gases (GHG) emissions were considered together, the AWDI irrigation system allowed for lower yield-scaled total global warming potential (GWP). Higher irrigation water productivity was achieved under AWDI in two of the three rice seasons. These findings suggest that AWDI could be an option for reducing GHG emissions and increasing irrigation water productivity. However, AWDI may compromise grain yield in certain years, reflecting the importance of the need for fine tuning of this irrigation strategy and an assessment of the overall tradeoff between relationships in order to promote its adoption by farmers.

Keywords: greenhouse gases, emissions, methane, nitrous oxide, mitigation

\section{Introduction}

Methane $\left(\mathrm{CH}_{4}\right)$ is the dominant greenhouse gas (GHG) produced in irrigated paddy rice fields, contributing approximately $15-20 \%$ to annual global $\mathrm{CH}_{4}$ emissions (Jacobson, 2005; Hadi et al., 2010). Flooded soils generate anaerobic conditions favoring the production of $\mathrm{CH}_{4}$ as an end product from organic matter degradation (Conrad, 2002). Water management is one of the most important tools for achieving high levels of production as well as a promising option for the mitigation of $\mathrm{CH}_{4}$. Changes in water management such as intermittent irrigation and mid-season drainage are effective options for the mitigation of $\mathrm{CH}_{4}$ in rice fields (Hadi et al., 2010; Itoh et al., 2011; Jain et al., 2013; Minamikawa and Sakai, 2006; Tyagi et al., 2010; Yagi et al., 1997). However, these practices of alternate anaerobic and aerobic cycling can stimulate the emission of another GHG, nitrous oxide $\left(\mathrm{N}_{2} \mathrm{O}\right)$, via denitrification and nitrification, respectively. Therefore, an optimum emission trade-off that minimizes emissions of both gases is highly desirable (Itoh et al., 2011; Zou et al., 2005). Furthermore, drainage systems are also important for conserving water and improving rice yields (Xu et al., 2007).

In Uruguay, rice yields are among the highest in the world, averaging $8000 \mathrm{~kg} \mathrm{ha}^{-1}$. Any alternative water management practice intended to reduce GHG emissions and to save water should not be detrimental to maintaining high rice yields. In dry-seeded rice systems, delaying permanent flooding during the vegetative stage of growth as much as possible is considered an acceptable practice aimed at minimizing GHG emissions and increasing water productivity. However, this water management system can induce crop water stress that can negatively affect the final rice yield (Dunn and Gaydon, 2011).

A large proportion of the world's rice is grown under continuous anaerobic conditions; thus, there is a lack of reports regarding the integrated effects of GHG emissions, water consumption and productivity on direct-seeded, delayed-flood rice production systems.

Based on this, the aim of this study was to compare the effect of conventional water management with continuous flooding after 30 days of emergence (CF30) with an alternative system of controlled deficit irrigation allowing for wetting and drying (AWDI) on GHG emissions, water productivity, and paddy rice yields in Uruguay.

\section{Materials and Methods}

\section{Site description}

A three-year experiment was conducted over the following consecutive rice (Oryza sativa) growing seasons: 2010-2011; 2011-2012; and 2012-2013, from October to March, in fields cultivated with a cultivar of indica origin, named El Paso 144, in the department of Treinta y Tres in the southeast of Uruguay, $\left(33^{\circ} 14^{\prime} \mathrm{S}\right.$, $54^{\circ} 23^{\prime}$ W, 21 m.a.s.1.). The soil was a Typic Argiudoll loamey clay. The main properties of the soil for the three rice growing seasons are described in Table 1. 
Crop (1-2 years of rice) - pasture (3-4 years) rotations have been the predominant cropping system in Uruguay since the 1960s. This rotational system maintains or increases fertility and thus allows for up to 70 $\mathrm{kg} \mathrm{N} \mathrm{ha-1}$ to be deployed which might, in turn, result in lower $\mathrm{N}_{2} \mathrm{O}$ emissions (García-Préchac et al., 2004). In this study, rice was seeded at a density of $150 \mathrm{~kg} \mathrm{ha}^{-1}$ after a three-year pasture.

Daily mean air temperature (measurements were taken at 9 a.m., 3 p.m. and 9 p.m.between 20 days before and 20 days after $50 \%$ flowering) was $23{ }^{\circ} \mathrm{C}$ over the three seasons studied. The mean air temperature and daily rainfall in the three seasons are shown in Figures $1 \mathrm{~A}$ and $1 \mathrm{~B}$, respectively.

\section{Experimental layout}

A complete randomized block design was used with two irrigation treatments in triplicate for three consecutive growing seasons. The two irrigation treatments were conventional water management (CF30) and an al-

Table 1 - Soil properties for the three rice growing seasons (OctoberMarch) in Treinta y Tres, Uruguay.

\begin{tabular}{lcccc}
\hline Season & $\mathrm{pH}\left(\mathrm{H}_{2} \mathrm{O}\right)$ & Organic matter & P Bray & Available K \\
\hline & & $\%$ & $\mu^{2} g^{-1}$ & meq $100 \mathrm{~g}^{-1}$ \\
1 & 6.0 & 2 & 5.0 & 0.12 \\
2 & 5.5 & 2 & 5.0 & 0.18 \\
3 & 6.3 & 2 & 2.2 & 0.16 \\
\hline
\end{tabular}

ternative controlled irrigation system (AWDI). CF30 consisted of a continuous flooding treatment applied 30 days after plant emergence and a $10-\mathrm{cm}$ water layer above the soil surface, maintained during the rest of the growing season until final drainage. This water management system is the one most frequently employed by Uruguayan rice producers. AWDI consisted of alternate wetting and drying irrigation where irrigation was given only at a certain number of days, after the soil had reached $50 \%$ depletion of the water available in the root zone. This treatment also started at 30 days after plant emergence (DAE) and continued until the panicle initiation stage, around 70 DAE. At this stage, the plots were flooded with a $10-\mathrm{cm}$ water layer similar to the CF30 system (Figure 2). Both treatments were direct-seeded and occasionally flushed during the first 30 days to prevent severe water stress depending on rainfall conditions. For both treatments, the irrigation end-point was set at 15 days after $50 \%$ of flowering and plots were drained 15 days before harvesting. Each plot of $66 \mathrm{~m}^{2}$ had an independent irrigation inlet where water inflow was measured using a water flow meter to record the amount of water used for irrigation.

Details of crop management activities are provided in Table 2.

\section{Gas sampling and flux measurement}

$\mathrm{CH}_{4}$ and $\mathrm{N}_{2} \mathrm{O}$ emissions were monitored using the static closed chamber technique as described for rice by
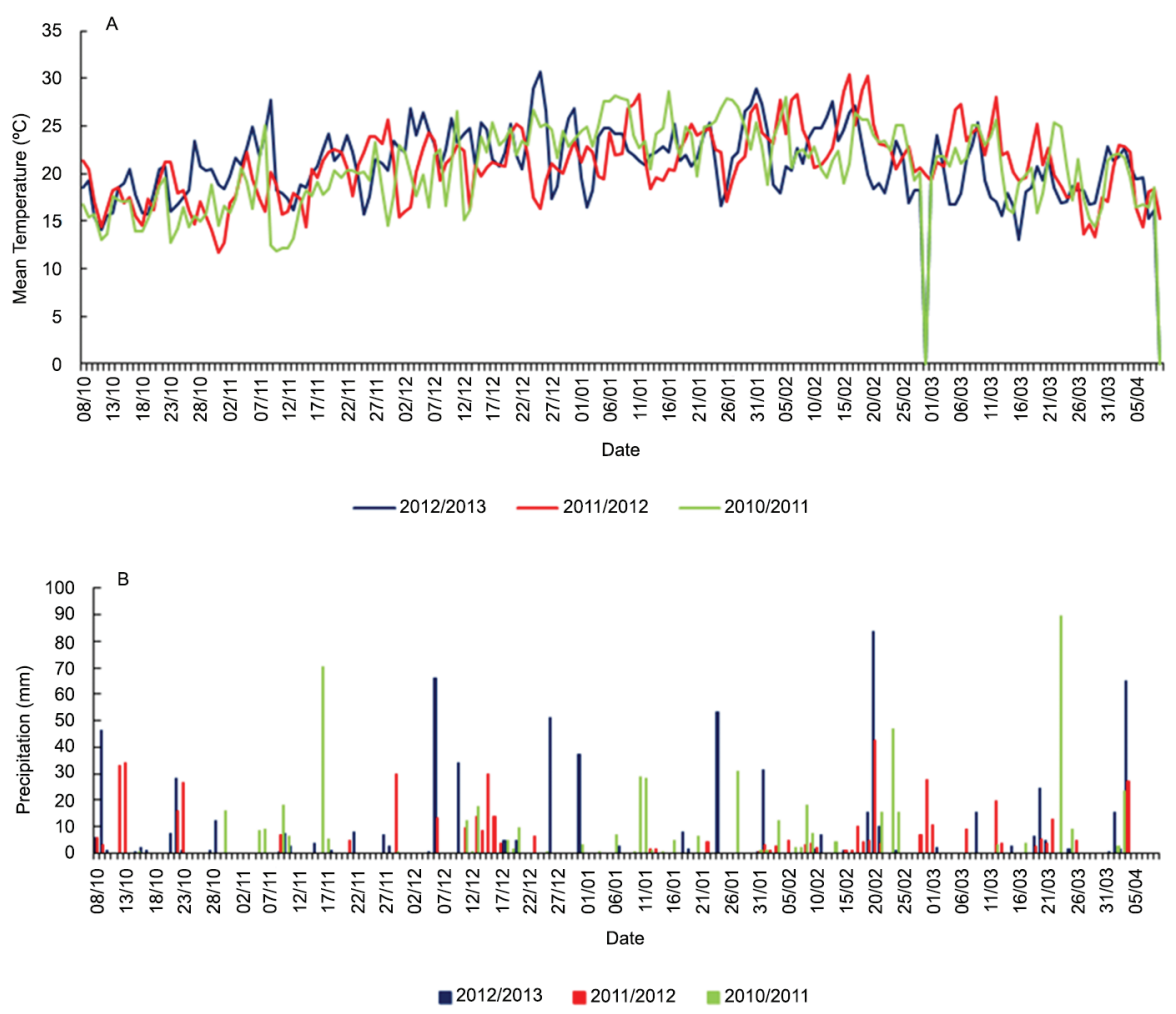

Figure 1 -Daily mean air temperature (A) and rainfall (B) during the three crop seasons in Treinta y Tres, Uruguay. 


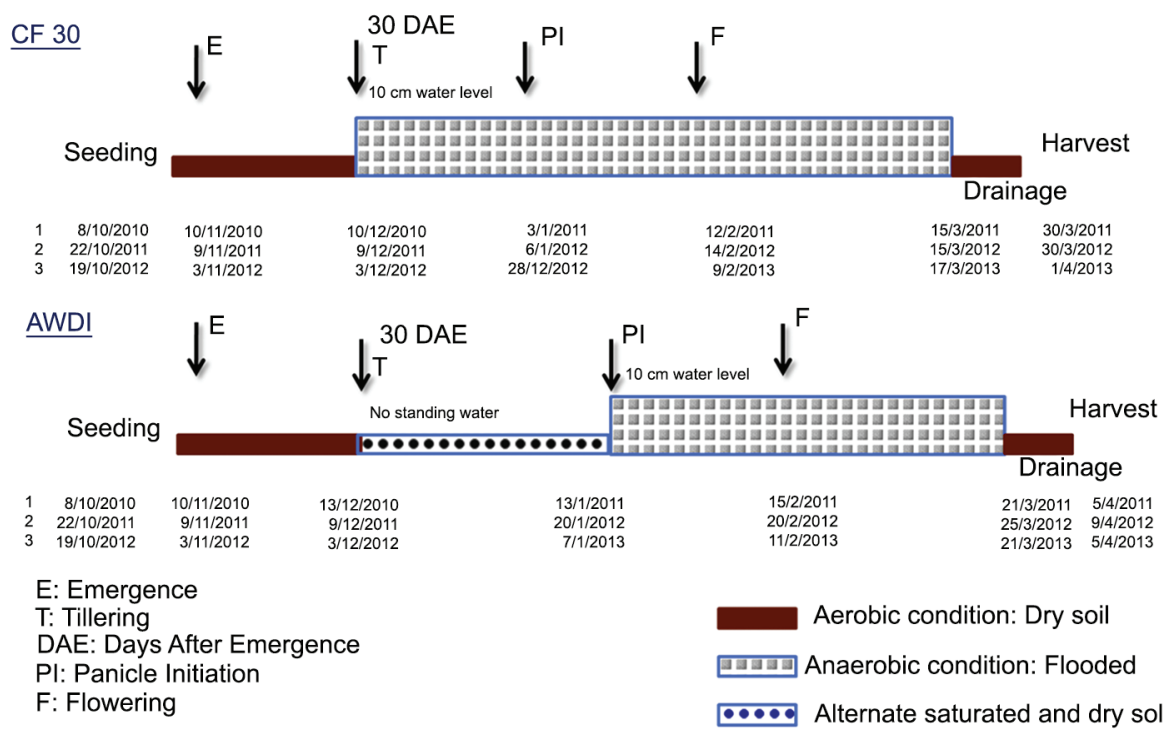

Figure 2 - Schematic of the rice crop cycle and irrigation treatments; CF30 = continuous flooding after 30 days of emergence; AWDI = controlled deficit irrigation allowing wetting and drying.

Table 2 - Seasonal sequence of rice crop management events during the three seasons in Treinta y Tres, Uruguay..

\begin{tabular}{|c|c|c|c|}
\hline \multirow{2}{*}{ Crop management } & Season 1 & Season 2 & Season 3 \\
\hline & DAE & DAE & DAE \\
\hline Planting and fertilization (16 kg ha-1 $\left.\mathrm{N}, 66 \mathrm{~kg} \mathrm{ha}^{-1} \mathrm{P}_{2} \mathrm{O}_{5}, 18 \mathrm{~kg} \mathrm{ha}^{-1} \mathrm{~K}_{2} \mathrm{O}\right)$ & -33 & -18 & -15 \\
\hline Plant emergence & $\begin{array}{c}0 \\
(10 / 11 / 2010)\end{array}$ & $\begin{array}{c}0 \\
(09 / 11 / 2001)\end{array}$ & $\begin{array}{c}0 \\
(03 / 11 / 2012)\end{array}$ \\
\hline Herbicide application & -11 and 9 & -10 and 13 & 9 and 26 \\
\hline Fertilization at tillering $\left(60 \mathrm{~kg}\right.$ urea ha-1) ${ }^{1}$ & 33 & 30 & 30 \\
\hline Fertilization at panicle initiation (50 kg urea ha-1) & $\begin{array}{l}\text { CF30: } 54 \\
\text { AWDI: } 64\end{array}$ & $\begin{array}{r}\text { CF: } 58 \\
\text { AWDI: } 72\end{array}$ & $\begin{array}{c}\text { CF:55 } \\
\text { AWDI: } 65\end{array}$ \\
\hline Flooding & $\begin{array}{l}\text { CF30: } 33 \\
\text { AWDI: } 64\end{array}$ & $\begin{array}{l}\text { CF30: } 30 \\
\text { AWDI: } 72\end{array}$ & $\begin{array}{l}\text { CF30: } 30 \\
\text { AWDI: } 65\end{array}$ \\
\hline
\end{tabular}

${ }^{1}$ Urea was applied in dry soil before flooding in CF30 (continuous flooding after 30 days of emergence) and before the first irrigation in AWDI (controlled deficit irrigation allowing wetting and drying); $\mathrm{DAE}=$ days after emergence.

Butterbach-Bahl et al. (2015). The assembly consisted of permanently installed stainless steel bases, $40 \mathrm{~cm}$ in diameter and $20 \mathrm{~cm}$ in height that were left in the place inserted $10 \mathrm{~cm}$ into the soil and enclosing approximately 12-14 rice plants. At each sampling date, acrylic boxes of $60 \mathrm{~cm}$ in height were placed on the bases and a water-seal was established to provide air-tight conditions. The chamber was equipped with a battery-operated circulating fan which was turned on 5 min before measurements to ensure complete gas mixing and a device to equilibrate pressure between the inside and the outside of the chamber. Gas samples from the chamber headspace were drawn using $25 \mathrm{~mL}$ plastic syringes at 0,30 and $60 \mathrm{~min}$ for $\mathrm{CH}_{4}$ and at 0,15 and $30 \mathrm{~min}$ for $\mathrm{N}_{2} \mathrm{O}$, carefully flushing the syringe three times before two replicates were stored in evacuated 12-mL glass vials with screw caps and septum until analysis. Two chambers were installed in each plot. Chamber temperature, floodwater depths and headspace heights were recorded and used to calculate gas flux rates from the soil surface to the chamber atmosphere assuming a linear increase in gas concentration over time. The frequency of flux measurements was generally every seven days which has been determined to be an accurate approach for estimating seasonal $\mathrm{CH}_{4}$ emissions from rice systems (Minamikawa et al., 2012). Gas flux measurements were taken between $10 \mathrm{~h} 00$ and $11 \mathrm{~h} 30$ a.m., as recommended by Minamikawa et al. (2012). The $\mathrm{CH}_{4}$ concentrations were analyzed on a GC-2014 gas chromatograph (Shimadzu Scientific) with a Porapak Q column equipped with an FID (flame ionization) detector. The $\mathrm{N}_{2} \mathrm{O}$ analysis was carried out on a gas chromatograph with an electronic capture detector (ECD), as described in Perdomo et al. (2009).

Overall gas emissions during the cropping season (from plant emergence to harvest) were calculated by integrating the fluxes over time. Seasonal $\mathrm{CH}_{4}$ and $\mathrm{N}_{2} \mathrm{O}$ 
were estimated by adding all mass flux values for the experimental period. The net gas mass flux between the two measurement dates was calculated taking the mean flux values of the two dates multiplied by the number of days between these dates (Bowden et al., 1990). Total Global Warming Potential (GWP) was calculated in terms of $\mathrm{CO}_{2}$ equivalents $\left(\mathrm{CO}_{2}\right.$ eq) over a 100-year time horizon using a radiative forcing potential of 298 for $\mathrm{N}_{2} \mathrm{O}$ and 25 for $\mathrm{CH}_{4}$ (Solomon et al., 2007). Yield-scaled GWP refers to GWP divided by grain yield in order to determine an agricultural efficiency value (Groenigen et al., 2010).

\section{Soil and plant measurements}

Water applied in the rice field under AWDI was based on cumulative crop evapotranspiration (ETm). The Penman-Monteith equation (FAO 56PM - Allen et al., 1998) was used to estimate potential evapotranspiration (ETo). The ETm was calculated multiplying ETo by an initial corrected crop coefficient value for rice $\left(\mathrm{K}_{\mathrm{c}}\right)$ of 0.8 and a medium value of 1.2 . Irrigation water was applied when cumulative ETm was equal to $50 \%$ depletion of the available water in the root zone. Precipitation data was registered at a meteorological station located at the experimental field and the soil water content was measured hourly every day in situ using a frequency domain reflectometry device (FDR), Decagon EC5, with 5-cm rod length, at a soil depth of 0-10. Irrigation water productivity and total water productivity were estimated by dividing the grain yield by irrigation water applied and by rainfall plus irrigation water applied, respectively.

Redox potential was measured weekly during 2012-13 season, using a Horiba D-52 manual platinum electrode which performs instantaneous value measurements. The measurements were taken between rows with a $10 \mathrm{~cm}$ depth and five replicates for each plot. Rice yields were assessed by crop-cut sampling in each plot using a $3 \times 2 \mathrm{~m}$ sampling frame. Reported grain yield refers to the weight of rough rice adjusted to $14 \%$ grain moisture content.

\section{Statistical analysis}

Differences for seasonal cumulative $\mathrm{CH}_{4}$ and $\mathrm{N}_{2} \mathrm{O}$ emissions, GWP, grain yield, and yield-scaled GWP were compared between irrigation treatments using a linear
Mixed Model. Irrigation treatment by cropping season interaction was considered a fixed-effect, while blocks and cropping season were included as random effects. If a significant interaction per cropping season was present, an analysis by cropping season was conducted to detect differences between treatments. The level of significance was determined as $p<0.05$.

\section{Results and Discussion}

\section{Water use and water productivity}

Table 3 shows variations in water consumption and water productivity. Significantly lower amounts of irrigation water were used in AWDI for seasons 1 and 3 (2010-2011 and 2012-2013). Season 3 required less amounts of irrigations during the period between planting and final flooding due to regular rainfall. Season 1 was characterized by a shortage of rainy days during the above-mentioned period with the intermediate occurrence of an event of heavy rainfall (above $60 \mathrm{~mm}$ ), while the rainfall pattern in season 2 was of a more irregular nature, no rainfall after seeding followed by some days of rain.

\section{Seasonal patterns of $\mathrm{CH}_{4}$ emissions}

For all years and irrigation treatments, a similar seasonal $\mathrm{CH}_{4}$ emission pattern was observed (Figure 3A and $3 \mathrm{~B}) . \mathrm{CH}_{4}$ emission increased gradually over time after flooding and reached an expressive peak in the late reproductive stage of the crop (before and around flowering in CF30 and around and after flowering in AWDI) after which emissions gradually declined until field drainage or harvesting. An exception to this behavior was observed in the 2010-2011 season for CF30 where a significant drop in $\mathrm{CH}_{4}$ emission was recorded around 98 DAE. The highest $\mathrm{CH}_{4}$ emission rates for CF30 ranged from 3948 to $4766 \mathrm{~g} \mathrm{ha}^{-1} \mathrm{~d}^{-1}$, significantly higher $(p=$ $0.0016)$ than for AWDI, which ranged from 2105 to 3189 $\mathrm{g} \mathrm{ha}^{-1} \mathrm{~d}^{-1}$ (Figure $3 \mathrm{~A}$ and $3 \mathrm{~B}$ ). After the beginning of the flooding, $\mathrm{CH}_{4}$ emissions achieved a peak between seven and nine weeks after flooding in CF30 and around six weeks after flooding in AWDI. Total $\mathrm{CH}_{4}$ emissions during the cropping period from CF30 were 208.2, 249.4 and $248.8 \mathrm{~kg} \mathrm{CH}_{4} \mathrm{ha}^{-1}$ and from AWDI were 93.3,

Table 3 - Rice crop water consumption and productivity for the three seasons and for the two irrigation systems evaluated, in Treinta y Tres, Uruguay.

\begin{tabular}{|c|c|c|c|c|c|}
\hline Season & Treatment & Irrigation water applied ${ }^{1}$ & Total water input ${ }^{2}$ & Irrigation water productivity & Total water productivity \\
\hline & & $-\mathrm{m}^{3} \mathrm{I}$ & & 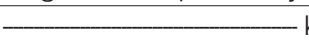 & \\
\hline \multirow{2}{*}{1} & CF 30 & $11208^{a}$ & $15905^{a}$ & $1.01^{\mathrm{a}}$ & $0.71^{\mathrm{a}}$ \\
\hline & AWDI & $7708^{b}$ & $12666^{\mathrm{b}}$ & $1.35^{\mathrm{b}}$ & $0.81^{\mathrm{a}}$ \\
\hline \multirow{2}{*}{2} & CF 30 & $8278^{a}$ & $11657^{a}$ & $1.23^{\mathrm{a}}$ & $0.82^{\mathrm{a}}$ \\
\hline & AWDI & $7017^{a}$ & $10667^{\mathrm{a}}$ & $1.25^{\mathrm{a}}$ & $0.87^{a}$ \\
\hline \multirow{2}{*}{3} & CF 30 & $6072^{a}$ & $11103^{a}$ & $1.65^{\mathrm{a}}$ & $0.88^{a}$ \\
\hline & AWDI & $4776^{b}$ & $10622^{b}$ & $2.00^{\mathrm{b}}$ & $0.89^{a}$ \\
\hline
\end{tabular}

${ }^{1}$ As interaction between season and treatment was significant, the analysis was performed by season; Different letters indicate differences between treatments ( $p<$ $0.05)$; 2lrrigation water applied + rainfall; CF30 = continuous flooding after 30 days of emergence; AWDI = controlled deficit irrigation allowing wetting and drying. 

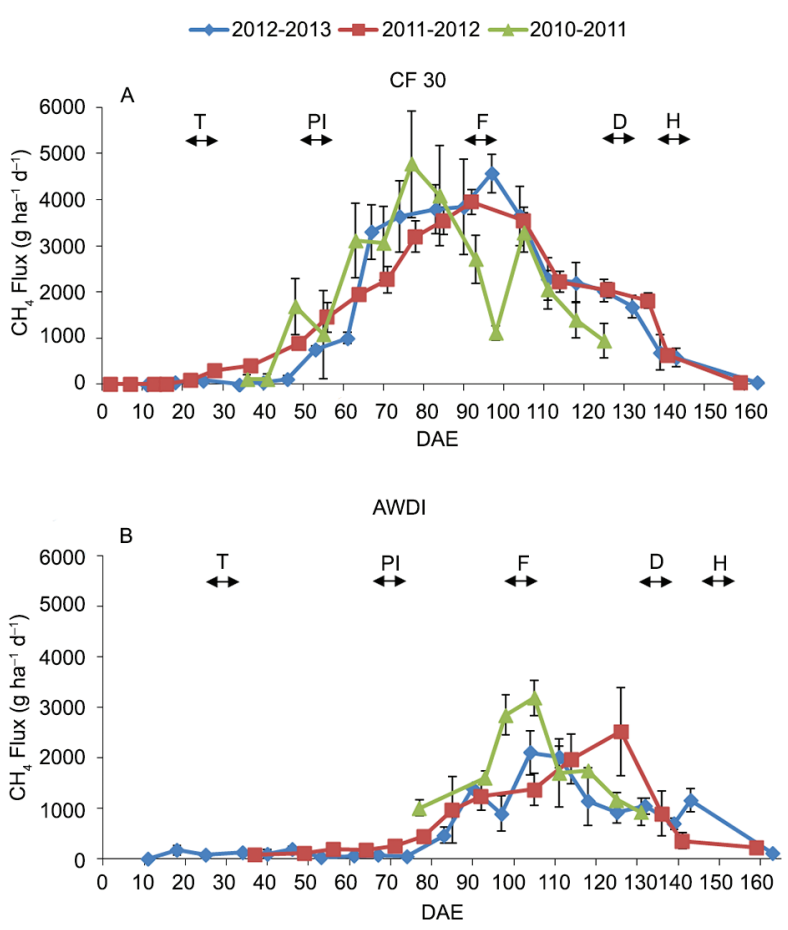

Figure 3 - Evolution of $\mathrm{CH} 4$ fluxes in the three rice crop seasons for the two irrigation treatments; A) CF30 (continuous flooding after 30 days of emergence); B) AWDI (controlled deficit irrigation allowing wetting and drying); Points are average fluxes and error bars represent the standard error of six replicates; DAE = days after emergence; Dates of tillering (T), panicle initiation (PI), flowering $(F)$, drainage $(D)$ and harvesting $(H)$ are indicated.

106.3 and $95.7 \mathrm{~kg} \mathrm{CH}_{4}$ ha $^{-1}$ (Table 4). Significantly lower fluxes were observed in season two and in season three for AWDI, accounting for a 57 and $62 \%$ reduction, respectively (Table 4). Even considering only the period when both irrigation treatments were flooded (from panicle initiation to drainage), the fluxes were significantly higher for CF30. Our estimates are consistent over the three seasons and comparable to previously published rates from rice fields from temperate countries. Reports from continuously irrigated systems include the following values of $\mathrm{kg} \mathrm{CH}_{4}$ ha $^{-1}$ : 634 (Hadi et al., 2010); 250 (Cicerone et al., 1992); 112-404 (Schütz et al., 1989); 200-500 (Gutierrez et al., 2013) from Japan, California, Italy and South Korea, respectively. Two continuously irrigated systems (direct-seeded, delayed flood) similar to ours have reported values of $270 \mathrm{~kg} \mathrm{CH}_{4}$ ha $^{-1}$ (Rogers et al., 2012) and 340-423 $\mathrm{kg} \mathrm{CH}_{4} \mathrm{ha}^{-1}$ (Moterle et al., 2013) from rice fields in Arkansas, USA, and southern Brazil, respectively.

Soil redox potential (Eh) was measured in the third year of the experiment. This parameter showed a different pattern under both water treatments (Figure 4). In CF30, soil redox potential was above $+300 \mathrm{mV}$ before flooding and then decreased sharply to a level of -100 $\mathrm{mV}$ within about 30 days after flooding (Figure 4).

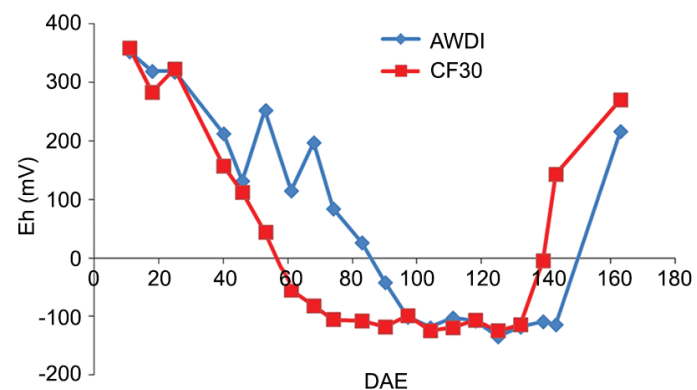

Figure 4 - Soil redox potential (10 cm depth) over time for rice crop season 2012-13 for the two irrigation treatments; Eh = soil redox potential; $\mathrm{DAE}=$ days after emergence; $\mathrm{AWDI}=$ controlled deficit irrigation allowing wetting and drying; CF30 = continuous flooding after 30 days of emergence.

Table 4 - Seasonal $\mathrm{CH}_{4}$ and $\mathrm{N}_{2} \mathrm{O}$ emissions and rice grain yield for two irrigation systems and three seasons, in Treinta y Tres, Uruguay.

\begin{tabular}{lcrcc}
\hline Season & Treatment & $\mathrm{CH}_{4}{ }^{1}$ & $\mathrm{~N}_{2} \mathrm{O}^{2}$ & Grain yield \\
\cline { 3 - 5 } & & & $\mathrm{kg} \mathrm{ha}^{-1}$ & \\
\cline { 3 - 5 } 1 & $\mathrm{CF30}$ & $208.2^{\mathrm{a}}$ & 0.3 & $11171^{\mathrm{a}}$ \\
& $\mathrm{AWDI}$ & $93.3^{\mathrm{a}}$ & 0.4 & $10170^{\mathrm{a}}$ \\
\hline \multirow{2}{*}{3} & $\mathrm{CF30}$ & $249.4^{\mathrm{a}}$ & 1.0 & $10387^{\mathrm{a}}$ \\
& $\mathrm{AWDI}$ & $106.3^{\mathrm{b}}$ & 1.2 & $8700^{\mathrm{b}}$ \\
\hline \multirow{2}{*}{3} & $\mathrm{CF30}$ & $248.8^{\mathrm{a}}$ & 0.6 & $9803^{\mathrm{a}}$ \\
& $\mathrm{AWDI}$ & $95.7^{\mathrm{b}}$ & 1.9 & $8992^{\mathrm{a}}$ \\
\hline
\end{tabular}

${ }^{1}$ As interaction between season and treatment was significant, the analysis was performed by season; Different letters indicate differences between treatments $(p<0.05)$; ${ }^{2}$ Seasonal $\mathrm{N}_{2} \mathrm{O}$ emissions were not different $(p>0.05)$; CF30 = continuous flooding after 30 days of emergence; AWDI = controlled deficit irrigation allowing wetting and drying.

On the other hand, Eh values for AWDI gradually decreased to $100 \mathrm{mV}$ until $46 \mathrm{DAE}$. This was followed by transient increases and decreases in the redox potential during intermittent drainage until the field was continuously flooded with standing water and Eh values turned negative (Figure 4). This soil Eh fluctuation between 10 and 70 DAE corresponds with the minimal $\mathrm{CH}_{4}$ flux detected in AWDI fields. This is expected because the soil Eh did not decline in this period to within an appropriate range favorable for the activity of methanogens. As a consequence, $\mathrm{CH}_{4}$ emission from AWDI was delayed compared to CF30. Soil water content variations reflected soil redox potential fluctuations (data not shown). As many previous studies have reported, the seasonal gradual $\mathrm{CH}_{4}$ emission pattern has been ascribed to the progressive development of anaerobic soil conditions during flooding, reaching a maximum around flowering due to the higher availability of substrates in the rice rhizosphere for methanogens responsible for $\mathrm{CH}_{4}$ production and followed by a decrease in $\mathrm{CH}_{4}$ efflux at the ripening stage of the crop due to reduced photosynthetic activity (Mitra et al., 2005; Pittelkow et al., 2013; Towprayoon et al., 2000; Wassmann et al., 2002). The absence of an emission peak early in the cultivation season in this study could be 
due to either the lack of organic amendment which has been reported to enhance $\mathrm{CH}_{4}$ emission or to inadequate conditions for anaerobic methanogenesis during the 30day delayed flooding due to posterior non-flooded fallow conditions (Itoh et al., 2011; Watanabe et al., 1999; Zhang et al., 2011). Alternate wet-dry conditions delayed the onset of $\mathrm{CH}_{4}$ emission as compared to continuously flooded plots. This pattern of a retarded initiation of $\mathrm{CH}_{4}$ emission has also been observed in mid-season and multiple drainage treatments (Itoh et al., 2011; Towprayoon et al., 2005; Tyagi et al., 2010). This decrease can be ascribed to temporary soil aeration generated due to partial drying of the soil that in turn suppresses methanogenic activity and may increase aerobic methanotrophic activity.

\section{Seasonal patterns of $\mathrm{N}_{2} \mathrm{O}$ emissions}

Figures $5 \mathrm{~A}$ and $5 \mathrm{~B}$ shows the pattern of $\mathrm{N}_{2} \mathrm{O}$ emission for both irrigation treatments in the three crop seasons. There was no clear seasonal pattern of $\mathrm{N}_{2} \mathrm{O}$ emission, either for the different seasons or treatments. Until 30 DAE when CF30 was flooded, the two irrigation treatments behaved similarly and one or two peaks of $\mathrm{N}_{2} \mathrm{O}$ fluxes were registered in all the seasons. These peaks of $\mathrm{N}_{2} \mathrm{O}$ fluxes prior to permanent flooding could not be correlated with rain events but the highest flux peaked after flushing in season 2011-2012 (65 $\left.\mathrm{g} \mathrm{N}_{2} \mathrm{O} \mathrm{ha}^{-1} \mathrm{~d}^{-1}\right)$.

In AWDI, $\mathrm{N}_{2} \mathrm{O}$ fluxes were detected until 90 DAE while in CF30 only until 60 DAE. The dry-wet alternation created a favorable environment for both nitrification and denitrification processes and probably enhanced soil available $\mathrm{C}$ released from organic matter and consequently denitrification activity that is mainly heterotrophic (Zou et al., 2007). The period when $\mathrm{N}_{2} \mathrm{O}$ fluxes were registered was longer in AWDI while $\mathrm{CH}_{4}$, on the contrary, was emitted during a shorter lapse in AWDI than in CF30 (Figures 3 and 5).

Once soils are waterlogged and negative redox potential values are reached (Figure 4), thermodynamics determines the sequential reduction of inorganic electron acceptors present such as nitrate, sulfate and iron (III) after which $\mathrm{CH}_{4}$ production is initiated (Conrad, 2002; Kögel-Knaber et al., 2010). Therefore, $\mathrm{N}_{2} \mathrm{O}$ emissions are not expected to occur under these anaerobic soil conditions that prevent nitrification and promote methanogenesis (Figures 3 and 5).

$\mathrm{N}_{2} \mathrm{O}$ seasonal emissions were not significantly different under either treatment (Table 4). The sporadic behavior of $\mathrm{N}_{2} \mathrm{O}$ fluxes has been acknowledged previously in different agricultural soils including rice systems (Perdomo et al., 2009; Pittelkow et al., 2013; Zhao et al., 2011). Numerous factors are involved in controlling $\mathrm{N}_{2} \mathrm{O}$ emissions from soils, which contribute to the huge spatiotemporal variation in emissions in field trials. As a consequence of the spatiotemporal variation, it has been reported that the power of statistical tests of such experiments is low (Bakken et al., 2012).

Soil moisture conditions and fertilizer management practices are the main factors that determine
$\mathrm{N}_{2} \mathrm{O}$ emissions from paddy soils (Guo and Zhou, 2007). However, in our experiment the peaks of $\mathrm{N}_{2} \mathrm{O}$ were not related to $\mathrm{N}$-fertilizer application (Figure $5 \mathrm{~A}$ and $\mathrm{B}$ ). Although excess fertilizer $\mathrm{N}$ doses result in high emissions, $\mathrm{N}_{2} \mathrm{O}$ emissions correlate poorly with the $\mathrm{N}$ fertilizer applied when they are within realistic ranges (Bakken et al., 2012). The demand-driven $\mathrm{N}$ supply minimizes the pool of excessive nitrogen in the soil and thus, reduces $\mathrm{N}_{2} \mathrm{O}$ emissions. At tillering the rice crop was actively growing and consequently the amount of soil mineral $\mathrm{N}$ left for losses was reduced. Total $\mathrm{N}$-fertilizer recovery in rice plants was $40 \%$ when the fertilizer was split versus a single dose application $(20 \%)$ in the same rice field of this experiment (Irisarri et al., 2007). An inverse relationship between $\mathrm{N}_{2} \mathrm{O}$ emission and $\mathrm{N}$ use efficiency had been clearly established previously (Dalal et al., 2003). The split fertilization used in this study, which is the recommended method of application for this crop in Uruguay, probably increased $\mathrm{N}$ use efficiency.

\section{Global warming potential in relation to irrigation systems}

When $\mathrm{CH}_{4}$ and $\mathrm{N}_{2} \mathrm{O}$ emissions are expressed as $\mathrm{CO}_{2}$ equivalents, AWDI lowered GWP to $54 \%$ (Table 5). The major contributor to GWP in CF30 and AWDI was $\mathrm{CH}_{4}$ which represented above $96 \%$ and between 95 and $81 \%$ of total GWP across years, respectively (Table 5). This is in agreement with previous reports on paddy soils that have shown that $\mathrm{N}_{2} \mathrm{O}$ emissions contribute much less to GWP than $\mathrm{CH}_{4}$ (Itoh et al., 2011; Pittelkow et al., 2013). It has also been reported that simultaneous minimization of both $\mathrm{CH}_{4}$ and $\mathrm{N}_{2} \mathrm{O}$ emissions cannot be maintained due to redox potential changes (JohnsonBeebout et al., 2009).

In addition to concern over $\mathrm{CH}_{4}$ emissions from rice fields, rice productivity needs also to be considered. Uruguayan rice yields are among the highest in the world and any change in water management strategy must make sure that this highly productive system is not negatively affected. As shown in Table 3, despite the fact that only in season 2 was the AWDI rice yield significantly lower in comparison to CF30; yield levels of AWDI were always lower. Yield-scaled GWP (Table 5) showed a reduction close to $50 \%$ for AWDI vs. CF30 thus indicating a potential treatment for rice GHG mitigation.

\section{Conclusions}

The results of this study are among the first to report GWP and yield-scaled GWP for two irrigation treatments in a dry-seeded, highly productive rice system and underpin the importance of water-management strategies for the simultaneous achievement of high yields, efficient water use and contribution to global agricultural GHG mitigation.

AWDI can reduce GHG emissions and increase water productivity. However, AWDI may compromise 
Table 5 - Global Warming Potential (GWP) and Yield scaled GWP for the three rice seasons, in Treinta y Tres, Uruguay..

\begin{tabular}{|c|c|c|c|c|c|c|}
\hline Season & Treatment & $\mathrm{CH}_{4} \mathrm{GWP}$ & $\mathrm{N}_{2} \mathrm{O}$ GWP & GWP reduction & Yield scaled GWP & Yield scaled GWP reduction \\
\hline & & $\mathrm{kg}$ & & $\%$ & $\mathrm{~kg} \mathrm{CO}_{2}$ eq kg grain yield ${ }^{-1}$ & $\%$ \\
\hline \multirow{2}{*}{1} & CF 30 & 5205 & 81 & & 0.47 & \\
\hline & AWDI & 2333 & 110 & 54 & 0.24 & 49 \\
\hline \multirow{2}{*}{2} & CF 30 & 6234 & 288 & & 0.63 & \\
\hline & AWDI & 2658 & 347 & 54 & 0.35 & 45 \\
\hline \multirow{2}{*}{3} & CF 30 & 6219 & 193 & & 0.65 & \\
\hline & AWDI & 2392 & 578 & 54 & 0.33 & 49 \\
\hline
\end{tabular}

$\mathrm{CF} 30=$ continuous flooding after 30 days of emergence; $\mathrm{AWDI}=$ controlled deficit irrigation allowing wetting and drying.
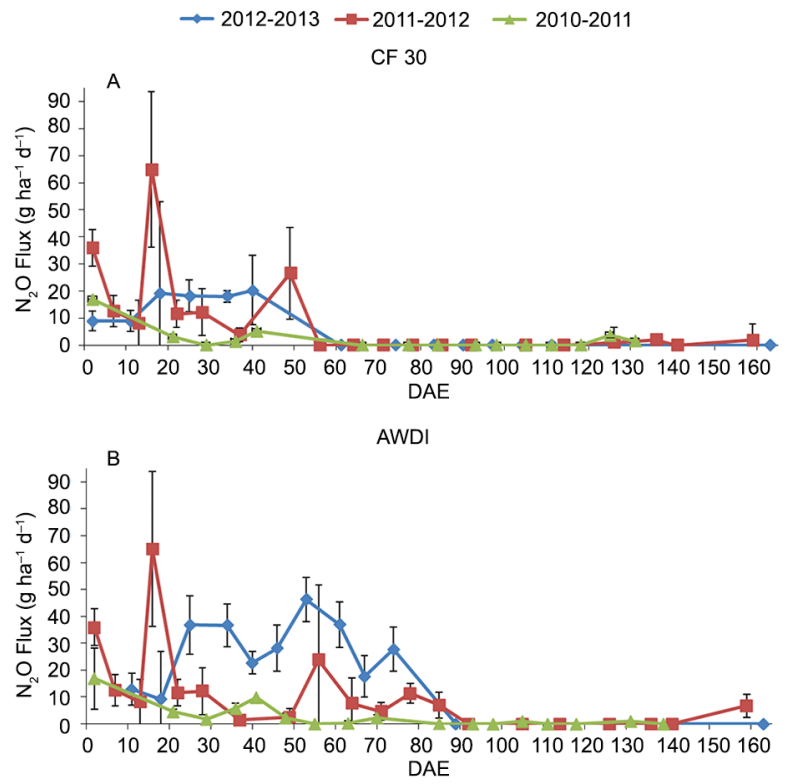

Figure 5 - Evolution of $\mathrm{N} 20$ fluxes in the three rice seasons for the two irrigation systems; A) CF30 (continuous flooding after 30 days of emergence); B) AWDI (controlled deficit irrigation allowing wetting and drying); Points are average fluxes and error bars represent the standard error of six replicates. $D A E=$ days after emergence.

grain yield, mainly in dryer seasons. Therefore, further AWDI irrigation strategies with less restrictive thresholds, (e.g. start of irrigation before reaching $50 \%$ depletion of available water) should be explored in order to avoid yield penalties. In addition, the overall tradeoffs between productivity, GWP emissions, and water use should be assessed in order to provide rice farmers with decision tools for the adoption of alternative irrigations systems.

\section{Acknowledgements}

S. Riccetto, I. Furtado, M. Oxley for soil and gas sampling. A. Martínez, F. Franco, S. Latorre and L. Pinelli for helping with chromatographic analyses. We also thank L. Gutierrez for statistical assistance.

\section{References}

Bakken, L.R.; Bergaust, L.; Liu, B.; Frostegård, Å. 2012. Regulation of denitrification at the cellular level: a clue to the understanding of $\mathrm{N}_{2} \mathrm{O}$ emissions from soils. Philosophical Transactions of the Royal Society B: Biological Sciences 367: 1226-1234.

Bowden, R.D.; Melillo, J.M.; Steudler, P.A.; Aber, J.D. 1990. Annual nitrous oxide fluxes from temperate forest soils in the northeastern United States. Journal of Geophysical Research 95: 13997-14005.

Butterbach-Bahl, K.; Sander, B.O.; Pelster, D.; Díaz-Penés, E. 2015. Quantifying greenhouse gas emissions from managed and natural soils. Available at: http://www.samples.ccafs.cgiar. org/soil-fluxes.html [Accessed Jun. 19, 2015]

Cicerone, R.J.; Delwiche, C.C.; Tyler, S.C.; Zimmerman, P.R. 1992. Methane emissions from California rice paddies with varied treatments. Global Biogeochemical Cycles 6: 233-248.

Conrad, R. 2002. Control of microbial methane production in wetland rice fields. Nutrient Cycling in Agroecosystems 64: 59-69.

Dalal, R.C.; Wang, W.; Robertson, G.P.; Parton, W. 2003. Nitrous oxide emission from Australian agricultural lands and mitigation options: a review. Australian Journal of Soil Research 41: 165-195.

Dunn, B.W.; Gaydon, D.S. 2011. Rice growth, yield and water productivity responses to irrigation scheduling prior to the delayed application of continuous flooding in South East Australia. Agricultural Water Management 98: 1799-1807.

García-Préchac, F.; Ernst, O.; Siri-Prieto, G.; Terra, J.A. 2004. Integrating no-till into crop-pasture rotations in Uruguay. Soil and Tillage Research 77: 1-13.

Groenigen, J.W. van; Velthof, G.L.; Oenema, O.; Groenigen, K.J. van; Kessel, C. van 2010. Towards an agronomic assessment of $\mathrm{N}_{2} \mathrm{O}$ emissions: a case study for arable crops. European Journal of Soil Science 61: 909-913.

Guo, J.; Zhou, C. 2007. Greenhouse gas emissions and mitigation measures in Chinese agroecosystems. Agriculture and Forest Meteorology 142: 270-277.

Gutierrez, J.; Kim, S.Y.; Kim, P.J. 2013. Effect of rice cultivar on $\mathrm{CH}_{4}$ emissions and productivity in Korean paddy soil. Fields Crop Research 146: 16-24.

Hadi, A.; Inubishi, K.; Yagi, K. 2010. Effect of water management on greenhouse gas emissions and microbial properties of paddy soils in Japan and Indonesia. Paddy and Water Environment 8: 319-324. 
Irisarri, P.; Gonnet, S.; Deambrosi, E.; Monza, J. 2007. Cyanobacterial inoculation and nitrogen fertilization in rice. World Journal of Microbiology and Biotechnology 23: 237-242. Itoh, M.; Sudo, S.; Mori, S.; Saito, H.; Yoshida, T.; Shiratori, Y.; Suga, S.; Yoshikawa, N.; Suzue, Y.; Mizukami, H.; Mochida, T.; Yagi, K. 2011. Mitigation of methane emissions from paddy fields by prolonging midseason drainage. Agricultural and Ecosystems Environment 141: 359-372.

Jacobson, M.Z. 2005. Atmospheric Pollution: History, Science and Regulation. Cambridge University Press, New York, NY, USA.

Jain, N.; Dubey, R.; Dubey, D.S.; Singh, J.; Khanna, M.; Pathak, H.; Bhatia, A. 2013. Mitigation of greenhouse gas emission with system of rice intensification in the Indo-Gangetic Plains. Paddy and Water Environment 12: 355-363.

Johnson-Beebout, S.E.; Angeles, O.R.; Alberto, M.C.R.; Buresh, R.J. 2009. Simultaneous minimization of nitrous oxide and methane emission from rice paddy soils is improbable due to redox potential changes with depth in a greenhouse experiment without plants. Geoderma 149: 45-53.

Kögel-Knaber, I.; Amelung, W.; Cao, Z.; Fiedler, S.; Frenzel, P.; Jahn, R.; Kalbitz, K.; Kölbl, A.; Schloter, M. 2010. Biogeochemistry of paddy soils. Geoderma 157: 1-14.

Minamikawa, K.; Sakai, N. 2006. The practical use of water management based on soil redox potential for decreasing methane emissions from a paddy field in Japan. Agricultural and Ecosystems Environment 116: 181-188.

Minamikawa, K.; Yagi, K.; Tokida, T.; Sander, B.O.; Wassmann, R. 2012. Appropriate frequency and time of day to measure methane emissions from an irrigated rice paddy in Japan using the manual closed chamber method. Greenhouse Gas Measurement and Management 2: 118-128.

Mitra, S.; Aulakh, M.S.; Wassmann, R.; Olk, D.C. 2005. Triggering of methane production in rice soils by root exudates: effects of soil properties and crop management. Soil Science Society of American Journal 69: 563-570.

Moterle, D.F.; Silva, L.S.; Moro, V.J.; Bayer, C.; Zschornack, T.; Avila, L.A.; Cas Bundt, A. 2013. Methane efflux in rice paddy field under different irrigation managements. Revista Brasileira de Ciencia do Solo 37: 431-437.

Perdomo, C.; Irisarri, P.; Ernst, O. 2009. Nitrous oxide emissions from an uruguayan argiudoll under different tillage and rotation treatments. Nutrient Cycling in Agroecosystems 84: 119-128.

Pittelkow, C.M.; Adviento-Borbe, M.A.; Hill, J.E.; Six , J.; van Kassel, C.; Linquist, B. 2013. Yield-scaled global warming potential of annual nitrous oxide and methane emissions from continuously flooded rice in response to nitrogen input. Agriculture Ecosystems and Environment 177: 10-20.

Rogers, C.W.; Brye, K.R.; Norman, R.J.; Gasnier, T.; Frizzell, D.; Branson, J. 2012. Methane emissions from a silt-loam soil under direct- seeded, delayed-flood rice management. p. 240247. In: Norman, R.J.; Moldenhauer, K.A.K., eds. University of Arkansas, Fayetteville, AR, USA. (Agricultural Experiment Station Research Series, 600).
Schütz, H.; Holzapfel-Pschorn, A.; Conrad, R.; Rennenberg, H.; Seiler, W. 1989. A 3-year continuous record on the influence of daytime, season, and fertilizer treatment on methane emission rates from an Italian rice paddy. Journal of Geophysical Research 94: 16405-16416.

Solomon, S.; Qin, D.; Manning, M.; Chen, Z.; Marquis, M.; Averyt, K.B.; Tignor, M.; Miller, H.L. 2007. Climate Change 2007: The Physical Science Basis. Cambridge University Press, New York, NY, USA.

Towprayoon, S.; Harvey, N.W.; Jittasatra, O.; Kerdchuchean, O. 2000. Influence of rice variety and soil type on production and emission of methane from rice fields. Asian Journal of Energy Environment 1: 251-262.

Towprayoon, S.; Smakgahn, K.; Poonkaew, S. 2005. Mitigation of methane and nitrous oxide emissions from drained irrigated rice fields. Chemosphere 59: 1547-1556.

Tyagi, L.; Kumari, B.; Singh, S.N. 2010. Water management: a tool for methane mitigation from irrigated paddy fields. Science of the Total Environment 408: 1085-1090.

Wassmann, R.; Aulakh, M.S.; Lantin, R.S.; Rennenberg, H.; Aduna, J.B. 2002. Methane emission patterns for rice fields planted to several cultivars for nine seasons. Nutrient Cycling Agroecosystems 64: 111-124.

Watanabe, A.; Takeda, T.; Kimura, M. 1999. Evaluation of origins of $\mathrm{CH}_{4}$ carbon emitted from rice paddies. Journal of Geophysical Research 104: 23623-23629.

Xu, S.R.; Jaffe, P.; Mauzerall, D.L. 2007. A process-based model for methane emission from flooded rice paddy systems. Ecological Modelling 205: 475-491.

Yagi, K.; Tsuruta, H.; Minami, K. 1997. Possible options for mitigating methane emission from rice cultivation. Nutrient Cycling in Agroecosystems 49: 213-220.

Zhang, G.; Zhang, X.; Ma, J.; Xu, H.; Cai, Z. 2011. Effect of drainage in the fallow season on reduction of $\mathrm{CH}_{4}$ production and emission from permanently flooded rice fields. Nutrient Cycling in Agroecosystems 89: 81-91.

Zhao, X.; Min, J.; Wang, S.; Shi, W.; Xing, G. 2011. Further understanding of nitrous oxide emission from paddy fields under rice/wheat rotation in south China. Journal of Geophysical Research 116: G02016.

Zou, J.; Huang, Y.; Jiang, J.; Zheng, X.; Sass, R.L. 2005. A 3 year field measurement of methane and nitrous oxide emissions from rice paddies in China: effects of water regime, crop residue, and fertilizer application. Global Biogeochemical Cycles 19: GB2021.

Zou, J.; Huang, Y.; Zheng, X.; Wang, Y. 2007. Quantifying direct $\mathrm{N} 2 \mathrm{O}$ emissions in paddy fields during rice growing season in mainland China: dependence on water regime. Atmospheric Environment 41: 8030-8042. 